\title{
PENYELESAIAN WANPRESTASI DALAM PERJANJIAN GADAI EMAS ANTARA NASABAH DENGAN PERSEROAN TERBATAS PEGADAIAN CABANG JAMBI
}

\author{
Oleh: \\ Abdul Hariss *
}

\begin{abstract}
ABSTRAK
Perseroan Terbatas (PT) Pegadaian (persero) adalah salah satunya badan usaha di Indonesia yang resmi memiliki izin untuk melaksanakan kegiatan penyaluran dana berdasarkan hukum gadai. Secara umum pengertian dari usaha gadai ini adalah kegiatan yang menjaminkan barang-barang berharga kepada pihak tertentu, guna memperoleh sejumlah uang dan barang yang akan dijaminkan akan ditebus kembali sesuai dengan perjanjian antara nasabah dengan lembaga gadai. Tujuan utama usaha pegadaian ini adalah supaya masyarakat yang membutuhkan uang atau dana tidak jatuh ke tangan para pelepas uang atau tukang ijon atau rentenir yang memberikan pinjaman dengan bunga yang relatif cukup tinggi. Lembaga gadai yang ada di Indonesia adalah pegadaian, pegadaian merupakan salah satu badan usaha milik negara (BUMN) yang memberikan kredit kepada masyarakat dengan menjamin gadai. Dulunya pegadaian yang berbentuk Perusahaan Umum (Perum) Negara yang bernaung dibawah departemen keuangan dan sekarang telah berubah menjadi Perseroan Terbatas (PT). Sejarah pegadaian berawal dari berdirinya Bank Van Leening di jaman VOC (Verenidge Oost Companny) yang bertugas memberikan pinjaman uang tunai kepada msyarakat dengan harta berharga. Pegadaian dalam perkembangannya mengalami perubahan, baik dalam bentuk usaha maupun perubahan status pengelolaannya. Misi utama PT. Pegadaian diatas, terlihat fungsi yang melekat pada PT. Pegadaian adalah untuk membantu masyarakat memperoleh dana dalam waktu yang relatif cepat dan mudah serta keberdaannya sangat di butuhkan masyarakat. Pemberian pinjaman pada PT. Pegadaian uang dilakukan sesuai dengan kondisi ekonomi masyarakat Indonesia, dimana masyarakat sering dihadapkan pada kebutuhan dana yang mendesak. Disamping itu keberadaan PT. Pegadaian secara langsung dapat memperkecil ruang gerak praktek pegadaian gelap, praktek ijon, rentenir dan bentuk riba lainnya, yang dirasakan cukup menekan dan memberikan masyarakat yang berpengasilan rendah. Dalam praktek di Kota Jambi, peminjaman pada PT. Pegadaian bukan hanya dari golongan ekonomi lemah bahkan golongan ekonomi ke atas pun sudah tidak merasa canggung dan malu lagi berhubungan dengan PT. Pegadaian, saat mereka membutuhkan dana yang mendesak, baik untuk keperluan rumah tangga maupun dalam menambah modal usahanya. Dalam pemberian pinjamannya pada PT. Pegadaian memberikan dua macam bentuk pinjaman yaitu pinjaman secara gadai dan fidusia. Pinjaman secara gadai yang menjadi agunannya tidak hanya terbatas alat rumah tangga, elektronik, dan perhiasan yang mudah dibawa ataupun dipindahkan. Sedangkan pinjaman secara fidusia barang agunannya meluputi surat kendaraan roda dua ataupun roda empat.
\end{abstract}

Kata Kunci : Perjanjian Gadai, Wanprestasi

* Pengajar Fakultas Hukum UNBARI 


\section{A. Latar Belakang}

Pada umumnya, setiap orang ataupun juga perusahaan selalu berhadapan dengan segala macam cara kebutuhan. Dalam hal menghadapi segala kebutuhan ini, manusia pada umunya ingin memenuhi segala kebutuhannya. Perkembangan kehidupan masyarakat semakin hari semakin meningkat sejalan dengan laju pertumbuhan ilmu pengetahuan dan teknologi. Demikian pula dengan kebutuhan yang semakin bertambah dan membawa personal dalam pemenuhannya. Kebutuhan akan menimbulkan suatu dorongan atau desakan alami untuk memutuskan kebutuhan tersebut dan adanya kecenderungan untuk mempertahankan hidup. Kebutuhan akan mudah terpenuhi bila sumber-sumber tersedia, tetapi apabila jumlahnya terbatas, maka manusia akan tertantang untuk memenuhi kebutuhan tersebut.

Perseroan Terbatas (PT) Pegadaian (persero) adalah salah satunya badan usaha di Indonesia yang resmi memiliki izin untuk melaksanakan kegiatan penyaluran dana berdasarkan hukum gadai. ${ }^{1}$ Secara umum pengertian dari usaha gadai ini adalah kegiatan yang menjaminkan barang-barang berharga kepada pihak tertentu, guna memperoleh sejumlah uang dan barang yang akan dijaminkan akan ditebus kembali sesuai dengan perjanjian antara nasabah dengan lembaga gadai. ${ }^{2}$ Tujuan utama usaha pegadaian ini adalah supaya masyarakat yang membutuhkan uang atau dana tidak jatuh ke tangan para pelepas uang atau tukang ijon atau rentenir yang memberikan pinjaman dengan bunga yang relatif cukup tinggi. ${ }^{3}$

Lembaga gadai yang ada di Indonesia adalah pegadaian, pegadaian merupakan salah satu badan usaha milik negara (BUMN) yang memberikan kredit kepada masyarakat dengan menjamin gadai. Dulunya pegadaian yang berbentuk Perusahaan Umum (Perum) Negara yang bernaung dibawah departemen keuangan dan sekarang telah berubah menjadi Perseroan Terbatas (PT). Sejarah pegadaian berawal dari berdirinya Bank Van Leening di jaman VOC (Verenidge Oost Companny) yang bertugas memberikan pinjaman uang tunai kepada msyarakat dengan harta berharga. Pegadaian dalam perkembangannya mengalami perubahan, baik dalam bentuk usaha maupun perubahan status pengelolaannya.

${ }^{1}$ Tri Hendro \& Conny Tjandra Rahardja, Bank \& Instusi Keuangan Non Bank di Indonesia, UPP STIM YKPN, Yogyakarta, 2014, Hal. 408

2 Kasmir, Bank \& Lembaga Keuangan Lainnya, Rajawali Pers, Jakarta, 2001, Hal. 230

${ }^{3}$ Ibid, Hal. 231 
Berdasarkan Staatblad 1901 No. 131 tanggal 12 Maret 1901, pada tanggal 1 April 1901 berdirinya kantor pegadaian yang berarti menjadi lembaga resmi pemerintah. Kantor pegadaian yang menjadi lembaga resmi pemerintahan tersebut berubah menjadi perusahaan negara pegadaian yang berdasarkan peraturan pemrintah Republik Indonesia tahun 1969 dikeluarkanlah Undang-Undang (UU) Republik Indonseia No.9 Tahun 1969 yang mengatur bentuk-bentuk usaha negara menjadi beberapa, antara lain adalah Perusahaan Jawatan (Perjam), Perusahaan Umum (Perum), dan Perusahaan Persero (Persero).

Dengan berjalannya waktu, perusahaan negara pegadaian berubah menjadi perusahaan jawatan. PT. Pegadaian memiliki maksud dan tujuan untuk melakukan usaha gadai dan fidusia, baik secara konvensional maupun syariah, dan jasa lainnya dibidang keuangan sesuai dengan ketentuan peraturan perundang-undangan terutama untuk masyarakat berpenghasilan menengah ke bawah, usaha mikro, usaha kecil, dan usaha menengah, serta optimalisasi pemanfaatan sumber daya perseroan dengan menerapkan prinsip perseroan terbatas. Kemudian untuk mencapai maksud dan tujuan itu maka persero melakukan kegiatan usaha utama berupa penyaluran pinjaman.

Setelah perusahaan negara pegadaian berubah lagi menjadi perusahaan jawatum, pemerintah meningkatkan status pegadain dari perusahaan jawatum menjadi perusahaan umum. Perubahan tersebut didasarkan pada Perturan Pemerintah (PP) No.10 Tahun 1990. Peran PT Pegadaian dalam lalu lintas kegiatan ekonomi, khususnya di Kota Jambi mempunyai misi utama, yaitu, turut melaksanakan dan menunjang pelaksanaan program pemerintahan dibidang ekonomi dan pembangunan daerah pada umumnya, dan mencegah praktek-praktek pegadaian gelap, sistem ijon, rentenir dan bentuk riba lainnya yang tidak sesuai dengan nilai-nilai Pancasila dan norma-norma agama.

Dari misi utama PT. Pegadaian diatas, terlihat fungsi yang melekat pada PT. Pegadaian adalah untuk membantu masyarakat memperoleh dana dalam waktu yang relatif cepat dan mudah serta keberdaannya sangat di butuhkan masyarakat. Pemberian pinjaman pada PT. Pegadaian uang dilakukan sesuai dengan kondisi ekonomi masyarakat Indonesia, dimana masyarakat sering dihadapkan pada kebutuhan dana yang mendesak. Disamping itu keberadaan PT. Pegadaian secara langsung dapat memperkecil ruang gerak praktek pegadaian gelap, praktek ijon, rentenir dan bentuk riba lainnya, yang dirasakan cukup menekan dan memberikan masyarakat yang berpengasilan rendah. 
Dalam praktek di Kota Jambi, peminjaman pada PT. Pegadaian bukan hanya dari golongan ekonomi lemah bahkan golongan ekonomi ke atas pun sudah tidak merasa canggung dan malu lagi berhubungan dengan PT. Pegadaian, saat mereka membutuhkan dana yang mendesak, baik untuk keperluan rumah tangga maupun dalam menambah modal usahanya.

Dalam pemberian pinjamannya pada PT. Pegadaian memberikan dua macam bentuk pinjaman yaitu pinjaman secara gadai dan fidusia. Pinjaman secara gadai yang menjadi agunannya tidak hanya terbatas alat rumah tangga, elektronik, dan perhiasan yang mudah dibawa ataupun dipindahkan. Sedangkan pinjaman secara fidusia barang agunannya meluputi surat kendaraan roda dua ataupun roda empat.

Pada tahun 2018 PT. Pegadaian cabang Jambi mengalami peningkatan jumlah wanprestasi dari tahun sebelumnya dilihat dari jumlah rekening tahun 2017 sebanyak 43 kasus dengan uang pinjaman sebesar Rp. 232.960.000, sementara jumlah rekening pada tahun 2018 sebanyak 56 kasus dengan uang pinjaman sebasar Rp. 386.040.000. ${ }^{4}$

Meningkatnya jumlah wanprestasi pada PT. Pegadaian Cabang Jambi disebabkan banyaknya nasabah yang melanggar perjanjian gadai yang telah disepakati oleh kedua belah pihak dalam bentuk keterlambatan pembayaran angsuran kepada PT. Pegadaian Cabang Jambi.

Dari uraian yang dipaparkan diatas, hal inilah yang menarik perhatian penulis untuk membahasnya dengan menuangkan kedalam bentuk penulisan karya ilmiah skripsi, dengan judul "Penyelesaian Wanprestasi Dalam Perjanjian Gadai Emas Antara Nasabah Dengan Perseroan Terbatas Pegadaian Cabang Jambi”.

\section{B. Perumusan Masalah}

Dari latar belakang masalah yang di paparkan diatas, dapat di klasifikasikan perumusan masalah yang akan diteliti adalah:

A. Bagaimana proses dalam penyelesaian wanprestasi dalam perjanjian gadai emas antara nasabah dengan PT. Pegadaian Cabang Jambi ?

B. Apa kendala dalam penyelesaian wanprestasi dalam perjanjian gadai emas antara nasabah dengan PT. Pegadaian Cabang Jambi ?

\footnotetext{
${ }^{4}$ Laporan Tahunan PT. Pegadaian Cabang Jambi Tahun 2017 dan 2018
} 
C. Bagaimana upaya penyelesaian wanprestasi dalam perjanjian gadai emas antara nasabah dengan PT. Pegadaian Cabang Jambi ?

\section{Pembahasan}

\section{A. Proses Dalam Penyelesaian Wanprestasi Dalam Perjanjian Gadai Emas Antara Nasabah Dengan Perseroan Terbatas Pegadaian Cabang Jambi}

Perseroan terbatas pegadaian merupakan perusahan yang menawarkan pinjaman uang yang berbentuk gadai barang maupun gadai secara fidusia. PT. pegadaian memberikan kemudahan dalam proses peminjaman uang. Namun demikian, tidak sedikit masyarakat yang melanggar perjanjian gadai dengan PT. pegadaian dengan berbagai macam alasan. Maka, pihak PT. pegadaian melakukan beberapa langkah untuk menyelesaikan pelanggaran perjanjian gadai tersebut, yaitu dengan satu peringatan persuasif, dua peringatan somasi, dan tiga lelang. Adapun penjelasannya yaitu:

\section{a.d. 1. Peringatan Persuasif}

Peringatan persuasif yaitu peringatan yang dilakukan pihak PT. Pegadaian melalui via telepon. Pihak kreditur mengirim pesan atau panggilan telepon berupa peringatan jatuh tempo dengan jangka waktu selama 120 hari atau 4 bulan.

\section{Tabel 1}

\section{Jumlah Nasabah Tahun 2017 dan Tahun 2018}

\begin{tabular}{|c|c|c|c|c|}
\hline No & Tahun & $\begin{array}{c}\text { Nasabah Yang } \\
\text { Melakukan Gadai } \\
\text { Emas }\end{array}$ & $\begin{array}{c}\text { Nasabah Yang } \\
\text { Wanprestasi Melalui } \\
\text { Pelunasan Atau Menebus } \\
\text { Barang Gadai }\end{array}$ & $\begin{array}{c}\text { Nasabah Yang } \\
\text { Wanprestasi Melalui } \\
\text { Lelang }\end{array}$ \\
\hline 1 & 2017 & 2.889 & 2.846 & 43 \\
\hline 2 & 2018 & 2.598 & 2.542 & 56 \\
\hline \multicolumn{2}{|c|}{ Total } & 5.487 & 5.542 & 99 \\
\hline
\end{tabular}

Dari tabel di atas pada tahun 2017 terdapat 2.889 nasabah yang melakukan gadai emas di PT. Pegadain Cabang Jambi, nasabah yang wanprestasi melalui pelunasan atau melunasi barang gadaiannya setelah mendapatkan pemberitahuan yang pertama yaitu peringatan persuasif 
sebanyak 2.846 nasabah, dan adapun nasabah yang melakukan wanprestasi melalui lelang sebanyak 43 nasabah.

Kemudian pada tahun 2018 terdapat terdapat 2.889 nasabah yang melakukan gadai emas di PT. Pegadain Cabang Jambi, nasabah yang wanprestasi melalui pelunasan melunasi barang gadaiannya setelah mendapatkan pemberitahuan yang pertama yaitu peringatan persuasif sebanyak 2.592 nasabah, dan adapun nasabah yang melakukan wanprestasi melalui lelang sebanyak 56 nasabah.

Jadi total nasabah yang melakukan gadai emas di PT. Pegadaian Cabang Jambi seabanyak 5.487 nasabah, total nasabah yang wanprestasi melalui pelunasan atau menebus barang gadai sebanyak 5.542 nasabah, dan adapun total nasabah yang melakukan wanprestasi melalui lelang sebanyak 99 nasabah

\section{a.d. 2. Peringatan Somasi}

Somasi adalah teguran dari berpiutang atau kreditur kepada si berutang atau debitur agar dapat memenuhi prestasi sesuai dengan isi perjanjian yang telah disepakatin anatara keduanya. Somasi timbul di sebabkan debitur tidak memenuhi prestasinya sesuai dengan yang di perjanjikan. Peringatan somasi yaitu peringatan yang diberikan pihak kreditur berupa surat panggilan pelunasan perjanjian gadai.

\section{a.d.3. Lelang}

Lelang adalah penjualan barang dihadapan banyak orang dengan tawar-menawar, tawaran tertinggi adalah pemenang. Lelang merupakan salah satu jenis jual beli dimana penjual menawarkan barang di tengah keramaian lalu para pembeli saling menawar dengan suatu harga. Namun akhirnya penjual akan menentukan, yang berhak membeli adalah yang mengajukan harga tertinggi.

\section{B. Kendala Dalam Penyelesaian Wanprestasi Dalam Perjanjian Gadai Antara Nasabah Dengan PT. Pegadaian Cabang Jambi}

Pelelangan atas barang jaminan tidak selamanya dapat terjual semuanya, dalam arti ada beberapa barang jaminan tertentu yang tidak laku dilelang, adapun kendala-kendala yang biasanya dihadapi pengelola dalam proses pelelangan barang jaminan disebabkan oleh beberapa faktor, antara lain, dunia usaha sedang lesu sehingga minat untuk membeli barang lelang 
menurun, karena biasanya barang lelang yang dibeli tersebut untuk dijual kembali. Banyak sekali masyarakat yang menginginkan barang lelang tersebut untuk dijual kembali. Dunia usaha menjadi lesu disebabkan oleh beberapa faktor yaitu barang yang dipesan atau dibutuhkan tidak ada, dalam lelang faktor ekonomi lemah sehingga pembeli tidak bisa membelinya, atau mungkin masyarakat memilih barang yang masih baru dengan pertimbangan kualitas barang yang lebih bagus. ${ }^{5}$

Kendala selanjutnya seperti tidak adanya pembeli barang lelang, hal tersebut juga disebabkan oleh faktor tingginya harga penawaran, barang yang dilelang cacat atau barang jaminan yang sudah lama atau kuno, atau harga dasar barang lelang yang ditentukan. Minat pembeli yang rendah dan harga dasar barang lelang yang cukup tinggi terkadang berakibat barang lelang tidak terjual habis. Hal tersebut terjadi bisa jadi karena barang jaminan yang telah dilelang nilainya tidak mencukupi pelunasan hutang nasabah, salah satu penyebabnya karena salah taksir harga.

Berdasarkan Buku Pedoman Operasional menyebutkan bahwa kesalahan dari pihak penaksir dalam hal taksiran yang terlalu tinggi sehingga menyebabkan kerugian maka penaksir akan diberi peringatan sesuai ketentuan yang berlaku. Setiap kerugian yang dilakukan oleh pegawai atau pengelola akibat kurang profesional dalam bekerja menjadi tanggungan pegawai atau pengelola, dan sangsi finalsial maupun administrasi akan diberikan kepada pegawai yang bersangkutan berdasarkan kebijakan Pimpinan Kantor Wilayah.

Hal lain yang menyebabkan tidak tercukupinya pelunasan hutang nasabah setelah lelang adalah nilai barang jaminan yang akan dilelang ternyata merosot, sehingga penerima barang jaminan berkewajiban bertanggung jawab atas hilangnya atau merosotnya harga barang yang digadaikan jika itu semua atas kelalaiannya. Oleh sebab itu untuk menghindari kewajiban memikul kerugian yang disebabkan karena suatu kejadian di luar kesalahan disalah satu pihak maka pihak PT. Pegadaian Cabang Jambi biasanya memberikan perlindungan terhadap barang jaminan nasabah kepada pihak ketiga yaitu melalui asuransi.

Kendala-kendala yang lain yaitu berubah-ubahnya seperti harga pasar terhadap barang jaminan sehingga menyulitkan dalam proses penaksiran oleh pengelola pegadaian, termasuk

5 Fausan Wahyu, Wawancara, Pimpinan Cabang PT. Pegadaian Cabang Jambi, Hari Kamis, Tanggal 5 Februari 2020, 09.00 WIB 
apabila harga barang diluar turun, pada waktu digadaikan harga barang tersebut tinggi tetapi pada waktu akan dilaksanakan lelang harga barang di luar turun padahal pihak pegadaian tidak ingin dirugikan, dalam proses pelelangan pihak pegadaian menginginkan harga yang setinggitingginya.

Faktor-faktor lain yang menjadi kendala yaitu proses pemberitahuan lelang yang tidak sampai pada pihak nasabah atau masyarakat, selanjutnya dikarenakan kurang memadai dan representatifnya tempat pelelangan di pegadaian, dan terakhir sulitnya pihak pengelola pegadaian dalam menjual Barang Sisa Lelang (BSL) atau barang jaminan gadai yang tidak laku dijual dalam pelelangan. Faktor-faktor penyebab tersebut pernah membuat pelaksanaan pelelangan tidak jadi dilaksanakan sesuai dengan jadwal yang telah ditentukan sebelumnya. ${ }^{6}$

Selain itu adapun kendala yang sering terjadi oleh PT. Pegadaian Cabang Jambi di dalam segi komunikasi ke nasabah. Nasabah pindah tempat tinggal tetapi tidak memberi tahukan ke pihak pegadaian dan nasabah sendiri tidak mengasi alamat tempat tinggal yang baru, hilangnya komunikasi atau kontak dengan hilangnya komunikasi antara nasabah dan PT. pegadaian sendiri mengakibatkan kesulitan memberikan informasi baik informasi peringatan jatuh tempo ataupun informasi pelelangan barang gadai tersebut secara via telepon atau via SMS. $^{7}$ Selanjutnya dijelaskan kendala yang dihadapi para nasabah, adalah keterlambatan pelunasan pinjaman gadai tersebut terkendalan dari segi ekonomi, sehingga mengalami kesulitan dalam pelunasan hutang gadai tersebut. ${ }^{8}$

Maka dapat disimpulkan bahwa kendala-kendala yang dihadapi pihak PT. Pegadaian Cabang Jambi dan pihak nasabah dalam melakukan pelelangan barang jaminan, adalah sebagai berikut :

1. Tidak adanya pembeli barang lelang dikarenakan model dari barang lelang tersebut telah lama yang mengakibatkan membeli barang lelang menurun.

2. Tidak adanya pembeli barang lelang, disebabkan oleh faktor tingginya harga penawaran, barang yang dilelang cacat atau barang jaminan yang sudah lama atau kuno, atau harga dasar barang lelang yang ditentukan kantor pusat pegadaian cukup tinggi sehingga tidak terjangkau oleh pembeli. Minat pembeli yang rendah dan harga dasar

\footnotetext{
${ }^{6}$ Ibid, 2020

7 Fikri, Wawancara, Penaksir, Hari Sabtu, Tanggal 8 Februari 2020, Jam 09.00 WIB

8 Lilis, Wawancara, Nasabah, Hari Minggu, Tanggal 9 Februari 2020, Jam 10.00 WIB
} 
barang lelang yang cukup tinggi terkadang berakibat barang lelang tidak terjual habis. Hal tersebut terjadi bisa jadi karena barang jaminan yang telah dilelang nilainya tidak mencukupi pelunasan hutang nasabah, salah satu penyebabnya karena salah taksir harga.

3. Berubah-ubahnya harga pasar terhadap barang jaminan sehingga menyulitkan dalam proses penaksiran oleh pengelola pegadaian, termasuk apabila harga barang diluar turun, pada waktu digadaikan harga barang tersebut tinggi tetapi pada waktu akan dilaksanakan lelang harga barang di luar turun padahal pihak pegadaian tidak sendiri ingin dirugikan, dalam proses pelelangan pihak pegadaian menginginkan harga yang setinggi-tingginya.

4. Proses pemberitahuan lelang yang tidak sampai pada pihak nasabah atau masyarakat.

5. Sulitnya pihak pengelola dalam menjual Barang Sisa Lelang (BSL) atau barang jaminan yang tidak laku dijual dalam pelelangan.

6. Hilangnya komunikasi dan alamat tempat tinggal nasabah ke pegadaian yang menyebabkan pihak pegadaian tidak bisa memberikan informasi jatuh tempo pelunasan maupun informasi akan dilelangnya barang jaminan gadai tersebut.

\section{Upaya Penyelesaian Wanprestasi Dalam Perjanjian Gadai Antara Nasabah Dengan PT. Pegadaian Cabang Jambi}

Lelang adalah penjualan barang dihadapan banyak orang dengan tawar-menawar, tawaran tertinggi adalah pemenang. Lelang merupakan salah satu jenis jual beli dimana penjual menawarkan barang di tengah keramaian lalu para pembeli saling menawar dengan suatu harga. Namun akhirnya penjual akan menentukan, yang berhak membeli adalah yang mengajukan harga tertinggi

Adapun proses lelang yang diterapkan di PT. Pegadaian cabang Jambi adalah sebagai berikut :

a. Pemberitahuan Lelang

Adapun waktu pelaksanaan lelang harus diumumkan melalui: papan pengumuman yang ada di kantor cabang, media infomasi lainnya berupa surat kabar, telepon dan lain-lain, pemberitahuan tertulis kepada pemilik barang. Pemberitahuan tertulis paling lambat diberikan 15 
hari sebelum pelaksanaan lelang, dan apabila ada barang bernilai tinggi yang akan dilelang barang ini sedapat mungkin di sebutkan dalam pemebritahuan.

b. Persiapan Lelang

Persiapan lelang di lakukan paling cepat 7 hari sebelum lelang, sedangkan kegiatan anatara lain mengeluarkan barang yang akan di lelang dari tempat penyimpanan, paling cepat 5 hari sebelum lelang, barang jaminan yang akan di lelang di cocokan dengan keterangan Surat Bukti Kredit (SBK) dwilipat (barang yang terbungkus pada waktu itu dibuka) serta kitirnya di gunting sedemikian rupa sehingga hanya tinggal nomornya saja. Nomor tersebut lalu di tempelkan atau diikat pada barang yang bersangkutan. Team pelaksanaan lelang harus menaksir ulang seluruh barang yang akan dilelang, hasil taksiran ulang tersebut di tulis pada halaman belakang dwilipat SBK. Jika taksiran baru lebih rendah dari taksiran lama, sehingga ada kemungkinan menimbulkan kerugian pada pihak perusahan atau nasabah, maka barang tersebut tidak boleh di lelang. ${ }^{9}$

\section{c. Pelaksanan Lelang}

Pada waktu lelang, team pelaksanaan lelang bertanggung jawab atas barang yang ada di tempat lelang. Oleh karena itu, kacuali team pelaksana lelang di larang berada di ruangan pelaksanaan lelang. Ketua team pelaksana lelang menyebut dengan suara yang sejelas-jelasnya, keterangan-keterangan singkat lelang di dasarkan pada penjualan tertinggi dan di setujui oleh panitia lelang. Pada akhirnya pelaksanaan lelang seluruh pendapatan lelang akan di pertanggung jawabkan kepada kepala cabang dan di butuhkan dalam buku kas harian sebagai pendapat lelang. d. Hasil Lelang

Barang jaminan yang tidak laku di lelang akan menjadi barang sisa lelang yang merupakan kerugian bagi perusahaan, atau dari barang sisa lelang tersebut akan di lelang untuk lelang berikutnya. Setiap barang yang tidak laku di lelang maka uang yang akan di bayar oleh pembeli harus di tambah 9\% ongkos lelang pembeli dan 7\% dana sosial. Dalam hal ini ongkos lelang pembeli $9 \%$ dan $0,7 \%$ dana sosial, di hitung dari jumlah lakunya lelang. ${ }^{10}$

Hasil penjualan lelang barang jaminan setelah dikurangi ulang pinjaman, sewa modal, biaya lainnya (jika ada), dan biaya lelang, merupakan kelebihan yang menjadi hak nasabah, PT.

\footnotetext{
9 Ibid, 2020

10 Ibid, 2020
} 
Pegadaian akan memberikan nominal untuk kelebihan nasabah melalui papan pengumuman di kantor cabang atau unit pelayanan cabang penerbit SBG, mengirimkan surat ke alamat nasabah atau melalui media lainnya seperti telepon atau short message service (SMS).

Jangka waktu pengambilan uang kelebihan lelang adalah 1 (satu) tahun sejak tanggal lelang, jika lewat waktu dari kurang waktu pengambilan uang lelang, nasabah menyatakan setuju untuk menyatakan uang kelebihan lelang tersebut sebagai dana kepedulian sosial yang pelaksanaannya di serahkan kepada PT. Pegadaian. Jika hasil penjualan barang lelang jaminan tidak mencukupi untuk melunaskan kewajiban nasabah berupa uang pinjaman, sewa modal, biaya lainnya (jika ada), dan biaya lelang maka nasabah wajib membayar kekurangan tersebut. ${ }^{11}$

\section{Kesimpulan dan Saran}

\section{Kesimpulan}

Adapun yang menjadi kesimpulan adalah sebagai berikut :

1. Proses penyelesaian Wanprestasi

Nasabah mendapatkan peringatan apabila tidak dapat melunasi barang jaminan yang telah di tetapkan dalam Surat Baukti Gadai (SBG) dengan jangka waktu selama 120 hati atau 4 (empat) bulan yang tercantum di halaman depan dari SBG tersebut yaitu berupa yaitu:

\section{Peringatan Persuasif}

2. Peringatan Somasi.

3. Lelang.

2. Hambatan dalam Penyelesain Wanprestasi

Kendala-kendala yang dihadapi pihak PT. Pegadaian Cabang Jambi dan pihak nasabah dalam melakukan pelelangan barang jaminan, sebagai berikut :

a. Tidak adanya pembeli barang lelang dikarenakan model dari barang lelang tersebut telah lama yang mengakibatkan membeli barang lelang menurun.

b. Berubah-ubahnya harga pasar terhadap barang jaminan sehingga menyulitkan dalam proses penaksiran oleh pengelola pegadaian.

c. Proses pemberitahuan lelang yang tidak sampai pada pihak nasabah atau masyarakat.

11 Fausan Wahyu, Wawancara, Pimpinan Cabang PT. Pegadaian Cabang Jambi, Hari Kamis, Tanggal 5 Februari 2020, 09.00 WIB 
d. Sulitnya pihak pengelola dalam menjual Barang Sisa Lelang (BSL) atau barang jaminan yang tidak laku dijual dalam pelelangan.

e. Hilangnya komunikasi dan alamat tempat tinggal nasabah ke pegadaian yang menyebabkan pihak pegadaian tidak bisa memberikan informasi jatuh tempo pelunasan maupun informasi akan dilelangnya barang jaminan gadai tersebut.

3. Upaya Penyelesaian Wanprestasi

Didalam upaya penyelesaian lelang tersebut yaitu dengan cara lelang, adapun proses lelang yang diterapkan di PT. Pegadaian cabang Jambi adalah sebagai berikut:

a) Pemberitahuan Lelang

b) Persiapan Lelang.

c) Pelaksanan Lelang, dan

d) Hasil Lelang

\section{Saran}

Sedangkan yang menjadi saran peneliti adalah, menguraikan dari pembahasan, kemudian menarik kesimpulan, melalui tulisan ini peneliti mengajukan saran yang mungkin dapat di gunakan :

1. Kepada PT. Pegadaian Cabang Jambi agar dapat mempertahankan dan meningkatkan cara penyelesaian penyelesaian wanprestasi dalam perjanjian gadai khususnya di Kota Jambi.

2. Kepada PT. Pegadaian lebih meningkatkan kinerja, lebih memadai tempat pelelangan dan lebih membuka pasar untuk menjual hasil dari barang lelangan tersebut.

3. Serta kepada masyarakat selalu memperbaharui nomor telepon maupun alamat tempat tinggal ketika membayar angsuran barang jaminan di PT. Pegadaian atau pun Unit Pelayaan Cabang (UPC) penerbit dari Surat Bukti Gadai (SBG).

\section{E. Daftar Pustaka}

Abdul Kadir Muhammad, Hukum Perikatan, Alumni, Bandung, 2004.

Burhan Bungi, Metode Penilitian Sosialisasi:Format-Format Kuatatif dan Kualitatif, Airlangga Universitas Press, 2001.

Djamanat Samosir, Hukum Jaminan, FH UHN, Medan, 2016. 
Abdul Hariss, Penyelesaian Wanprestasi dalam Perjanjian Gadai Emas Antara Nasabah dengan Perseroan Terbatas Pegadaian Cabang Jambi

Kartini Muljadi \& Gunawan Widjaja, Perikatan Yang Lahir Dari Perjanjian, PT. Raja Grafindo Persada, Jakarta, 2004.

Kasmir, Bank \& Lembaga Keuangan Lainnya, Rajawali Pers, Jakarta, 2001.

Mariam Darus Badrul Zaman, Bab-Bab Tentang Credictverband Gadai dan Fiducia, PT. Citra Aditnya Bakti, Bandung, 1991.

Mgs Edi Tje Aman, Kredit Perbankan Suatu Tinjauan Yuridis, Penerbit Liberty, Yogyakarta, 1985.

M. Yahya Harapan, Segi-Segi Hukum Perjanjian, Alumni Bandung, 2001.

R. Subekti, Hukum Perjanjian, Intermasa, Jakarta, 1992. , Pokok-Pokok Hukum Perdata, Intermasa, Jakarta, 2000. , Hukum Perjanjian, PT. Intermasa, Jakarta, 2002.

, Hukum Perikatan, PT. Intermasa, Jakarta, 2005.

Salim H.S., Hukum Kontrak:Teori \& Teknik Penyusunan Kontrak, Sinar Grafika, Jakarta, 2013. Sayuti Una, Pedoman Penelitian Skripsi (edisi revisi), Syariah Press, Jambi, 2011.

Soerjono Soekanto dan Sri Mamudji, Penelitian Hukum Normatif Satuan Tinjauan Singkat, Rajawali Press, Jakarta, 1988.

Tri Hendro dan Conny Tjandra Rahardja, Bank \& Instusi Keuangan Non Bank di Indonesia, UPP STIM YKPN, Yogyakarta, 2014.

Wirjono Prodjodikoro, Azas-Azas Hukum Perjanjian, PT.Bale, Bandung, 1999.

Yahma,"Karakteristik Wanprestasi dan Tindak Pidana Penipuan", Prenada Media Group, Jakarta, 2014. 